\title{
Directional Valve Device
}

National Cancer Institute

\section{Source}

National Cancer Institute. Directional Valve Device. NCI Thesaurus. Code C50245.

A valve designed to control the flow of fluid in a hydraulic system. 